\title{
Vestigial prototroch in a basal nemertean, Carinoma tremaphoros (Nemertea; Palaeonemertea)
}

\author{
S. A. Maslakova, ${ }^{a, c, *}$ M. Q. Martindale, ${ }^{b}$ and J. L. Norenburga \\ aSmithsonian Institution, National Museum of Natural History, MRC 163, P.O. Box 37012, Washington, DC 20013-7012, USA \\ ${ }^{b}$ Kewalo Marine Laboratory, University of Hawaii, 41 Ahui Street, Honolulu, HI 96813, USA \\ 'Department of Biology, George Washington University, 2023 G Street NW, Washington, DC 20052, USA \\ *Author for correspondence (email: maslak@gwu.edu)
}

SUMMARY Nemerteans have been alleged to belong to a protostome clade called the Trochozoa that includes mollusks, annelids, sipunculids, echiurids, and kamptozoans and is characterized by, among other things, the trochophore larva. The trochophore possesses a prototroch, a preoral belt of specialized ciliary cells, derived from the trochoblast cells. Nemertea is the only trochozoan phylum for which presence of the trochophore larva possessing a prototroch had never been shown. However, so little is known about nemertean larval development that comparing it with development of other trochozoans is difficult. Development in the nemertean clade Pilidiophora is via a highly specialized planktonic larva, the pilidium, and most of the larval body is lost during a drastic metamorphosis. Other nemerteans (hoplonemerteans and palaeonemerteans) lack a pilidium, and their development is direct, forming either an encapsulated or planktonic "planuliform" larva, producing a juvenile without a dramatic change in body plan. We show that early in the development of a member of a basal nemertean assemblage, the palaeonemertean Carinoma tremaphoros, large squamous cells cover the entire larval surface except for the apical and posterior regions. Although apical and posterior cells continue to divide, the large surface cells cleavage arrest and form a contorted preoral belt. Based on its position, cell lineage, and fate, we suggest that this belt corresponds to the prototroch of other trochozoans. Lack of differential ciliation obscures the presence of the prototroch in Carinoma, but differentiation of the trochoblasts is clearly manifested in their permanent cleavage arrest and ultimate degenerative fate. Our results allow a meaningful comparison between the development of nemerteans and other trochozoans. We review previous hypotheses of the evolution of nemertean development and suggest that a trochophore-like larva is plesiomorphic for nemerteans while a pilidium type of development with drastic metamorphosis is derived.

\section{INTRODUCTION}

Nemerteans (ribbon worms) belong to one of the least studied bilaterian phyla (Turbeville 2002). Some controversy still exists in the literature as to the phylogenetic affinities of nemerteans. Although some authors traditionally view them as related to platyhelminthes based on similarity in structure and origin of the nervous system and larval ciliated bands (Nielsen 2001), others consider them related to coelomate animals, such as annelids and mollusks, based on ultrastructural similarity of the nemertean rhynchocoel and blood vessels to the coelomic cavities (Turbeville and Ruppert 1985; Turbeville 1986). DNA sequence data support the coelomate affinities of nemerteans and place them within the clade of coelomate protostomes, often referred to as the Trochozoa, which includes animals with such diverse adult body plans as annelids, mollusks, sipunculids, echiurids, and kamptozoans (Turbeville et al. 1992; Peterson and Eernisse 2001; Turbeville 2002). Traditionally, the Trochozoa united animals that possess spiral cleavage and trochophore-type larvae. Although the core composition of the Trochozoa (annelids, mollusks, sipunculids, echiurids, and kamptozoans) remained undisputed over the last few decades, various authors argued for the inclusion of phoronids, bryozoans, and arthropods (Beklemishev 1964) or platyhelminthes and nemerteans (IvanovaKazas 1985). Rouse (1999) suggested an apomorphy-based taxon, Trochozoa, that includes the first ancestor to have evolved a prototroch and all its descendants. Based on this definition, the Trochozoa encompasses annelids (sensu lato), echiurids, sipunculids, mollusks, and kamptozoans. Here we adopt the more recent scope of the Trochozoa based on the combined phylogenetic analysis of morphological and molecular data (Peterson and Eernisse 2001). These authors apply the name Trochozoa to a clade comprising annelids, echiurids, sipunculids, mollusks, kamptozoans, and nemerteans. The only difference in terms of the scope of the Trochozoa is that Rouse's Trochozoa does not include the Nemertea. However, if nemerteans are shown to possess the prototroch 
(as is the conclusion of this manuscript), they become part of the Trochozoa by Rouse's definition as well. All trochozoans possess spiral cleavage. However, not all spiralians are currently included in the Trochozoa; the Platyhelminthes (some of which possess typical spiral cleavage) appear to be separated from the Trochozoa by a number of nonspiralian taxa, such as Lophophorata (Phoronida and Brachipoda), Cyclyophora, Acanthocephala, Rotifera, Gnathostomulida, and Ectoprocta (Peterson and Eernisse 2001).

The trochophore larva is the first swimming stage of the Trochozoa. The preoral belt of specialized ciliary cells, called the prototroch, characterizes the trochophore larva and is derived from specific founder cells, called trochoblasts. The prototroch is the primary locomotory organ of the trochophore larva and is derived from subsets of the same cell lineages across all trochozoan taxa. As emphasized by Rouse (1999, 2000), a more strictly defined trochophore, with prototroch, metatroch, gastrotroch, telotroch, a pair of protonephridia, and a downstream mechanism of larval ciliary feeding (Nielsen 1995), is only present in a few annelid taxa. Morphological cladistic analysis (Rouse 1999) suggests that metatroch and other "trochs" might have evolved multiple times independently within the Trochozoa, whereas the prototroch had evolved only once. Here we adopt the broad definition of the trochophore (Rouse 1999) based on the presence of the prototroch, derived from the trochoblast cell lineage. Upon development of a functional gut, the prototroch sometimes becomes involved in feeding. It is often suggested that the prototroch's function in downstream larval feeding is plesiomorphic for all trochophore larvae (Nielsen 2001). In contrast, recent cladistic evidence (Rouse 2000) suggests that the prototroch evolved primarily as a locomotory organ and became involved in feeding secondarily on several occasions during the radiation of the Trochozoa.

The central cells of the prototroch are referred to as primary trochoblasts and derive from the four vegetal daughters of the first quartet micromeres from each primary cell quadrant (A-D) at the 16-cell stage. These cells are designated as $1 \mathrm{q}^{2}$ micromeres in the classical nomenclature of spiral cleavage (Wilson 1892, modified by Child 1900). A unique feature of the primary trochoblasts is their ability to autodifferentiate. Isolated primary trochoblasts of annelids and mollusks follow the normal course of development observed in the intact embryo. They undergo one or two divisions, become cleavage arrested, and differentiate as ciliated cells (Wilson 1904; Costello 1945). Additional cells derived from the animal daughters of the first quartet micromeres (called accessory trochoblasts, derived from the $1 \mathrm{q}^{1}$ micromeres) and the second quartet micromeres (called secondary trochoblasts, derived from the $2 \mathrm{q}$ micromeres) also contribute to the prototroch, but they require additional cell-cell interaction for their differentiation (Damen and Dictus 1994a). In all trochozoans, the prototroch is a transitory larval structure that is shed or reabsorbed during development and does not contribute to the adult body plan (Buckland-Nicks et al. 2002a,b; Jaeckle and Rice 2002; Nielsen 2002; Pernet et al. 2002; Pilger 2002; Zardus and Martel 2002). Although most authors assume homology of trochophore larvae throughout the Trochozoa (Nielsen 2001), some consider appearance of the prototroch-bearing larvae in various taxa to be the result of parallel evolution, driven by the functional requirements of a swimming larva and constrained by the stereotypic nature of spiral cleavage (Ivanova-Kazas 1986). Morphological cladistic evidence supports homology of the prototroch in the Trochozoa and thus the trochophore larva, as broadly defined by the presence of the prototroch (Rouse 1999).

Nemertea is the only trochozoan phylum for which presence of a trochophore larva (with prototroch derived from trochoblasts) had never been shown. There also are no clearly recognized homologies between nemertean larvae and a typical trochophore (Norenburg and Stricker 2002), although many authors compare the ciliated band of the nemertean pilidium larva to the prototroch (McBride 1914; Lacalli and West 1985; Nielsen 2001). Peterson and Eernisse (2001) in their morphological analysis of metazoan phylogeny coded nemerteans as possessing a trochophore, basing this on $\mathrm{Ni}$ elsen's (1995) inference that trochoblasts underlie the ciliary band in pilidium larvae of heteronemerteans (Nielsen 1995). This particular hypothesis of homology was later refuted by cell lineage data for a pilidium larva (Henry and Martindale 1998). Nemerteans display a variety of developmental modes, the best studied of which is the development of the pilidium (Salensky 1886; Dawydoff 1940; Cantell 1969; Lacalli and West 1985; Henry and Martindale 1998 and references therein). The juvenile worm develops from a series of ectodermal invaginations (imaginal discs) and hatches out of the larval body in a drastic metamorphosis in which most larval ectodermal and mesodermal tissues are destroyed. Members of the Hoplonemertea and the Palaeonemertea have direct development where either a juvenile or a nonspecialized uniformly ciliated "planuliform" planktonic larva hatches out of the egg envelopes (Delsman 1915; Hammarsten 1918; Iwata 1960; Jägersten 1972; Stricker and Reed 1981; Martindale and Henry 1995; Maslakova and Malakhov 1999; Norenburg and Stricker 2002). The development of the planuliform larvae of palaeo- and hoplonemerteans is considered to be "direct" because the larva, where present, does not possess a distinctly different body plan from that of the juvenile and adult. However, many "planuliform" larvae of hoplo- and palaeonemerteans possess larval structures that do not contribute to the juvenile, such as eyes, apical organ, transitory larval ectoderm, and ciliary bristles or cirri (Maslakova and Malakhov 1999; Chernyshev 2000; Norenburg and Stricker 2002 and references therein). The traditional view is that the pilidium is derived within nemerteans, whereas the development with a nonspecialized planuliform larva is ancestral 
(Ivanova-Kazas 1985; Norenburg and Stricker 2002). A recent molecular phylogeny of nemerteans (Thollesson and Norenburg 2003) suggesting that palaeonemerteans represent a basal paraphyletic assemblage, whereas heteronemerteans (together with nonheteronemertean species possessing pilidia) and hoplonemerteans represent monophyletic sister groups supports this hypothesis (Fig. 1). However, evidence for a transitory larval ectoderm that is lost or reabsorbed during development of "planuliform" larvae, in several hoplonemertean (Delsman 1915; Reinhardt 1941; Hickman 1963; Maslakova and Malakhov 1999) and palaeonemertean (Iwata 1960) species, has led several authors to propose that a pilidial type of development with a drastic metamorphosis might be ancestral for the phylum (Jägersten 1972; Starobogatov 1979; Maslakova and Malakhov 1999). It is difficult to directly compare nemertean larvae to trochophore larvae because so little is known about the development of nonpilidial nemertean larvae. We provide evidence that supports the notion that the transitory larval epithelium of palaeonemerteans is homologous to the transitory larval structures of other trochozoans (i.e., trochoblast derivatives) and not to tissues involved in pilidial metamorphosis (i.e., the derivatives of pretrochal and trochal lineages).

\section{MATERIALS AND METHODS}

\section{Confocal microscopy}

Embryos of C. tremaphoros were obtained and raised as described in Maslakova et al. (2004). For confocal microscopy, larvae were fixed in $4 \%$ paraformaldehyde at $4{ }^{\circ} \mathrm{C}$ at $10,15,20,25,30$, and $36.5 \mathrm{~h}$ after fertilization and washed and stored in phosphate buffer saline (PBS) at $4{ }^{\circ} \mathrm{C}$ for up to 2 months. Larvae of the older ages (30 and $36.5 \mathrm{~h}$ ) were relaxed in a $1: 1$ mixture of $7.5 \% \mathrm{MgCl}_{2}$ and seawater before fixation to avoid muscular contraction. Fixed larvae were subsequently washed in PBT $(0.1 \%$ Triton X-100 in PBS) to permeabilize the cell membranes, counterstained with the

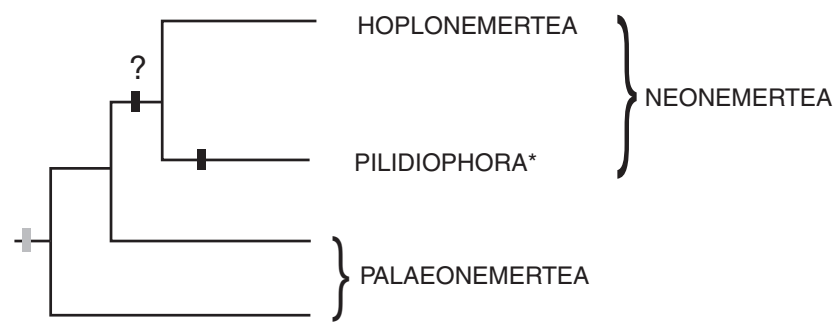

Fig. 1. Nemertean phylogeny after Thollesson and Norenburg (2003). Black rectangle indicates the hypothesized origin of the necrotic type of development. Gray rectangle indicates the hypothesized origin of development with the modified trochophore as found in Carinoma tremaphoros. ${ }^{*}$ Pilidiophora comprises the Heteronemertea and the nonheteronemertean species possessing a pilidium.
F-actin-binding Alexa Fluor Phalloidin (Molecular Probes Inc., Eugene, OR, USA) for $40 \mathrm{~min}$ to facilitate visualization of the larval morphology, washed in PBS, mounted in Vectashield on poly-L-lysine pretreated slides, and viewed on a Nikon E-800 Eclipse microscope with the Bio-Rad Radiance 2100 confocal system (Bio-Rad, Hercules, CA, USA) equipped with argon-ion and helium-neon lasers. To visualize the green (Alexa Fluor Phalloidin) label, argon laser was set to emit at $488 \mathrm{~nm}$.

\section{Scanning electron microscopy}

For scanning electron microscopy, 10-, 20-, 30-, and 36.5-h larvae were fixed by the semisimultaneous method described in Lacalli and Gilmour (2001). An equal volume of $2 \%$ glutaraldehyde in $0.2 \mathrm{M}$ sodium cacodylate with $6 \%$ sucrose was added dropwise to the seawater containing larvae. After $2 \mathrm{~min}$, the total volume was doubled again by addition of $4 \%$ osmium tetroxide. Specimens were left for $1 \mathrm{~h}$ in the mixed fixative and then washed thoroughly in distilled water, gradually dehydrated in alcohol series and then in acetone, and critical-point dried before being mounted on stubs. Larvae of older ages (30 and $36.5 \mathrm{~h}$ ) were relaxed in a 1:1 mixture of $7.5 \% \mathrm{MgCl}_{2}$ and seawater before fixation to prevent muscular contractions. Specimens were viewed on a JSM 6400 Visions scanning microscope by JEOL USA (Peabody, MA, USA).

\section{RESULTS}

Carinoma tremaphoros is a typical example of a benthic infaunal nemertean with a planktonic dispersal stage (larva). Adults inhabit the top $10-15 \mathrm{~cm}$ of sand between high and low tide marks. Females release up to several hundred relatively small $(100-110 \mu \mathrm{m})$ eggs protected by a very thin egg chorion and are initially embedded loosely in gelatinous mucus. Eggs are fertilized externally and develop into planktonic larvae. Although we were able to keep the larvae alive in the culture for up to a month, we did not observe feeding or settlement. Unfed larvae gradually diminished in size and degenerated.

The early development of $C$. tremaphoros is described in detail elsewhere (Maslakova et al. 2004). At $24^{\circ} \mathrm{C}$, embryos became ciliated at $4 \mathrm{~h}$ and began gastrulating at $5 \mathrm{~h}$ after fertilization. Uniformly ciliated spherical gastrulae possessing a long apical tuft hatched out of the egg envelope at approximately $5.5 \mathrm{~h}$ after fertilization. At $10 \mathrm{~h}$ after fertilization, an actively swimming, uniformly ciliated, spherical gastrula was formed (Fig. 2A). Gastrulae possessed a vegetal blastopore, gut, apical tuft, and a pair of lateral invaginations at the apical pole, most likely corresponding to the rudiments of the nervous system (Fig. 2, E and I). Dorsoventral polarity of the larva is apparent from the shape of the gut that is curved toward the dorsal side (Fig. 2E) and the asymmetric arrangement of the cells around the blastopore, with the group of small cells located in the dorsal quadrant (Fig. 3). The surface of the larva is covered by 40 large squamous cells except for 

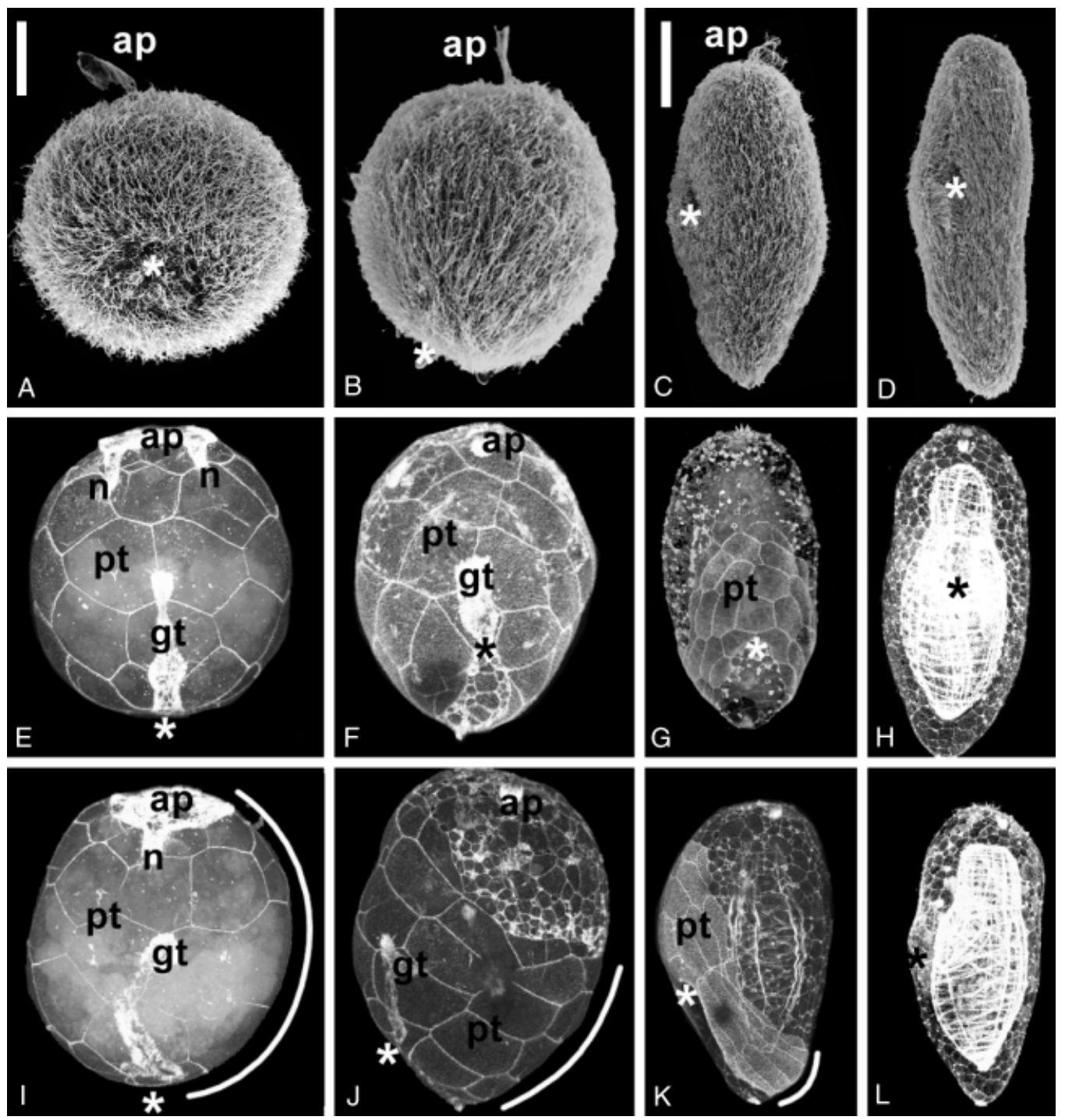

Fig. 2. Larval development of Carinoma tremaphoros. (A-D) Scanning electron microscopy images. (E-H) Confocal microscopy images, ventral view. (I-L) Confocal microscopy images, right side view. (A, E, I) $10 \mathrm{~h}$ old. (B, F, J) $20 \mathrm{~h}$ old. Scale, $25 \mu \mathrm{m}$. (C, G, K) $30 \mathrm{~h}$ old. (D, H, L) $36.5 \mathrm{~h}$ old. Scale, $50 \mu \mathrm{m}$. Note that the large ectodermal cells forming the prototroch disappear in the 36.5 -h-old larvae. *, blastopore (mouth); ap, apical organ; gt, gut; n, nervous system rudiments; pt, prototroch cells. White arched lines in I-K mark the dorsal area occupied by the prototroch, which gradually diminishes over the course of larval development.

the apical region and a small area at the vegetal pole posterior (dorsal) to the blastopore, shown in Figure 3. The large surface cells are arranged more or less in five rows, each containing eight cells. These 40 large cells thus form a very broad and continuous preoral (preblastoporal) belt.

During the next $10 \mathrm{~h}$ of development, the uniformly ciliated larva gradually elongated and the blastopore became shifted toward the ventral side (Fig. 2, B, F, and J). As can be inferred from the cell lineage analysis (Maslakova et al. 2004), shifting of the blastopore to the ventral side is a result of the faster rates of cell proliferation of the dorsal quadrant in both the apical and the vegetal regions. The 40 large surface cells described above remained cleavage arrested and formed an increasingly more distinct contorted belt. The cells of the belt changed shape slightly and shifted but maintained the neighbor relationships: the ventral region of the belt became broader than the dorsal as the whole belt assumed an oblique position with respect to the anterior-posterior axis of the larva. The "N"-shaped gut can be subdivided into three distinct regions at this stage. The mouth, derived from the blastopore, leads into the esophagus, parallel to the anterior-posterior axis of the larva and directed upward. The short middle region connects the esophagus to the main region of the gut situated centrally along the anterior-posterior axis (Fig. 2J). 

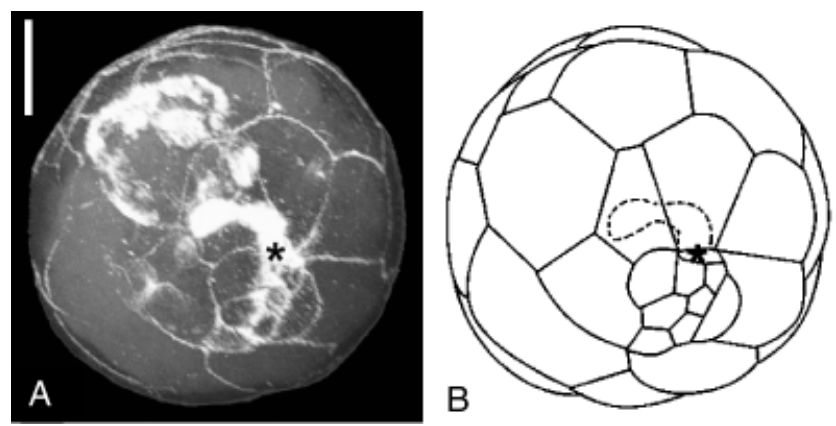

Fig. 3. The confocal image and the diagram of cell outlines of the 10-h-old larva of Carinoma tremaphoros showing the small cells in the dorsal quadrant (view from the blastoporal side). Scale, $25 \mu \mathrm{m}$. (A) Confocal projection. (B) Diagram showing cell outlines. *, blastopore (mouth).

The gut ends blindly at this stage; neither formation nor presence of the anus was observed.

The general architecture of the larval musculature first became evident around 20-24 h after fertilization. Four dorsal longitudinal muscular strands are followed by the lateral and ventral longitudinal muscles. The circular and diagonal musculature of the body wall developed by $30 \mathrm{~h}$. By $24 \mathrm{~h}$ the presumed rudiments of the cerebral ganglia (paired ectodermal invaginations at the apical pole) were almost completely closed (Fig. 2, F and J). Left-right asymmetry of the larval body became evident at this stage as a single ventrolateral eye developed just to the right off the midline.

At $30 \mathrm{~h}$ after fertilization, the uniformly ciliated larva continued to elongate, up to about $200 \mu \mathrm{m}$. As at the earlier stages, there was no visible difference in ciliation between the modified surface cells forming the belt and the rest of the ectoderm (Fig. 2C). Proliferating small cells of the apical and dorsoposterior regions moved the ventral mouth further toward the anterior end. Large cleavage-arrested surface cells diminished in size and shifted to form a relatively compact, oblique, preoral belt (Figs. 2, G and K, and 4). The difference in cell size between the cleavage-arrested cells of the belt and the proliferating cells of the anterior and posterior regions is dramatic (Fig. 4). Longitudinal, circular, and diagonal musculature of the body wall differentiated, forming a muscular cylinder. The esophagus became surrounded by the well-developed circumpharyngeal muscles. At $36.5 \mathrm{~h}$, the cleavagearrested cells forming the belt disappeared completely (Fig. 2, $\mathrm{H}$ and $\mathrm{L}$ ), presumably by apoptosis.

\section{DISCUSSION}

The position and fate of the preoral belt of specialized cells in the larvae of C. tremaphoros strongly resemble those of the prototroch of other trochozoans. The exact cell composition
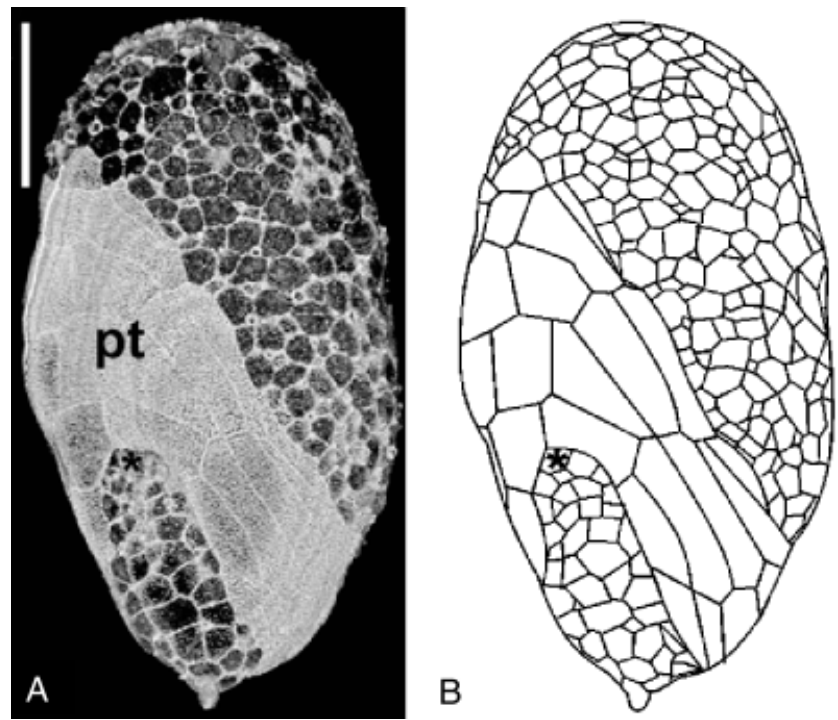

Fig. 4. The confocal image and the diagram of cell outlines of the 30-h-old larva of Carinoma tremaphoros showing the difference in cell size of the epidermal cells. (Ventral-left view). Scale, $50 \mu \mathrm{m}$. (A) Confocal projection. (B) Diagram showing cell outlines. *, blastopore (mouth); pt, prototroch cells.

of prototrochs in annelids and mollusks (the best-studied trochozoans) varies somewhat between species. However, the total number of cells commonly is $28-40$, and in all known cases these are derived from subsets of the same cell lineages (Damen and Dictus 1994b). Carinoma's alleged prototroch comprises 40 cells that are cleavage arrested, gradually diminish in size over the course of larval development, and disappear, presumably undergoing cell death. Furthermore, cell lineage analysis of C. tremaphoros embryos (Maslakova et al. 2004) reveals that these 40 cells are derived from the same lineages of embryonic precursors as the prototrochs of other trochozoans. As in other trochozoans, four primary trochoblasts $\left(1 \mathrm{a}^{2}-1 \mathrm{~d}^{2}\right)$ of Carinoma each divide twice and produce 16 central cells of the prototroch (Fig. 5). Various numbers and arrangements of accessory (vegetal-most progeny of the $1 q^{1}$ ) and secondary (animal-most progeny of $2 q$ ) trochoblasts are found among different mollusks and annelids. In these animals, the dorsal (D) quadrant typically gives rise to fewer accessory and secondary trochoblasts than other quadrants (Damen and Dictus 1994b). Interestingly, in Carinoma each quadrant, including $\mathrm{D}$, contributes three accessory and three secondary trochoblasts, so that 12 cells are derived from the $1 \mathrm{q}^{1}$ micromeres (homologous to accessory trochoblasts in other trochozoans) and 12 cells are derived from the 2q micromeres (homologous to secondary trochoblasts in other trochozoans) (Fig. 5; Maslakova et al. 2004). Although the lack of differential ciliation obscures the presence of the prototroch in Carinoma (hence the "hidden" trochophore), it can be easily recognized as a preoral belt composed of 

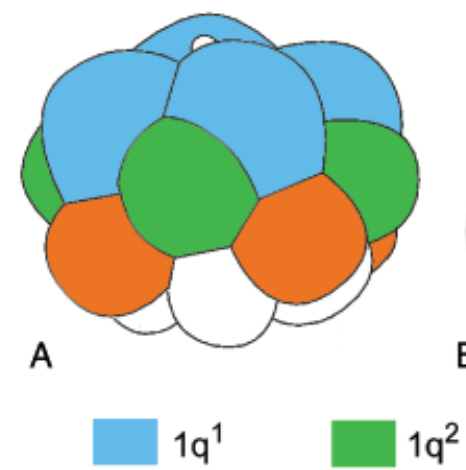

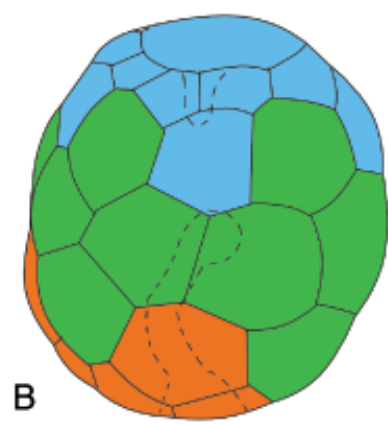

$2 q$
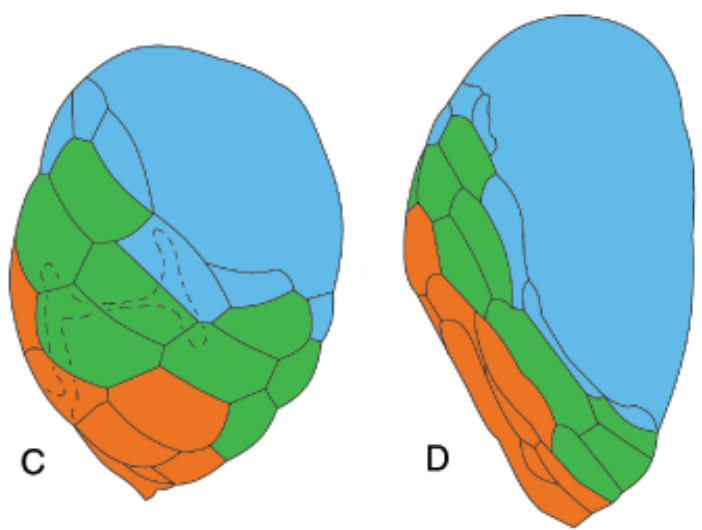

Fig. 5. Cell lineage of the developing prototroch in Carinoma tremaphoros. (A) The 16-cell stage. (B) 10-h-old larva. (C) 20-h-old larva. (D) 30-h-old larva. The 16 central cells of the prototroch are derived from the primary trochoblast cell lineage $\left(1 \mathrm{q}^{2}\right)$. The 12 accessory trochoblasts are derived from the $1 \mathrm{q}^{1}$. The 12 secondary trochoblasts are derived from the second quartet micromeres (2q).

40 specialized cells on confocal projections. Differentiation of the nemertean trochoblasts is manifested in their cleavage arrest and ultimate degenerative fate, characteristic of trochoblasts of other trochozoans. Although it is beyond the scope of this study, staining with acridine orange and ethidium bromide or a TUNEL assay could determine whether this is an example of programmed cell death, as we would predict.

Although primary trochoblasts of annelids and mollusks have been experimentally shown to undergo autodifferentiation, nothing is known about the mode of trochoblast specification in nemerteans. Blastomere isolation experiments on the hoplonemertean Nemertopsis bivittata, which also makes a planuliform larva, suggest that cell fates are specified as early as the four-cell stage (Martindale and Henry 1995). More comprehensive cell isolation experiments in the heteronemertean Cerebratulus lacteus (Henry and Martindale 1994; Martindale and Henry 1995) show an uncharacteristic ability of nemertean embryos to regulate development, a feature not seen in any other Trochozoan. An analysis of the developmental potential of blastomeres, including the trochoblasts in palaeonemerteans, is clearly needed.

Experiments on trochoblast specification in the gastropod mollusk Patella vulgata revealed the leading role of the $3 \mathrm{D}$ macromere (spiralian organizer) in the modification of the dorsoventral organization of the prototroch (Damen and Dictus 1996). Trochoblast specification appears to occur in all four quadrants initially, and then accessory and secondary lineages become modified by the influence of the 3D organizer. In this context, radial symmetry (in terms of the lineage contributions) of the prototroch in Carinoma, confirmed by the cell lineage data (Maslakova et al. 2004), suggests that the role of the spiralian organizer in development of the nemertean prototroch is either lacking/reduced or that all the trochoblasts in Carinoma (including the primary, accessory, and secondary lineages) are "immune" to the influence of the organizer, just as the primary trochoblasts of other spiralians are "immune" to the action of the organizer. If the latter is true, this may be a case of lineage fate change, that is, the accessory and secondary trochoblast lineages "accept the fate" of the primary trochoblasts.

In most other trochozoans (except sipunculids), the prototroch remains perpendicular with respect to the anteriorposterior axis of the larva, even following the morphogenetic movements of gastrulation (Buckland-Nicks et al. 2002a,b; Jaeckle and Rice 2002; Nielsen 2002; Pernet et al. 2002; Pilger 2002; Zardus and Martel 2002). In Carinoma, the prototroch becomes increasingly more distorted by morphogenetic movements during the course of larval development. Just after hatching and until about $10 \mathrm{~h}$ after fertilization, the cells of the prototroch occupy most of the larval ectoderm and the prototroch is perpendicular to the anterior-posterior axis of the body. However, later in development, the dorsal region of the prototroch is pushed more and more toward the posterior end by proliferating cells of the $\mathrm{D}$ quadrant in the pretrochal region $\left(1 \mathrm{q}^{1}\right.$ derivatives), whereas the ventral portion of the prototroch retains its original position (Fig. 5). Faster rates of proliferation of the dorsal ectodermal domain are characteristic of spiralian development. However, in all other trochozoans they are restricted to the posttrochal area (e.g., the primary somatoblast, 2d). Fast rates of proliferation of the $\mathrm{D}$ quadrant in both pretrochal and posttrochal areas (implied from the position of the blastopore and the prototroch) are unique features of Carinoma (Maslakova et al. 2004). Labeling experiments on the hoplonemertean Nemertopsis bivittata (Henry and Martindale 1994) also indicate possible faster rates of proliferation of the $\mathrm{D}$ and $\mathrm{C}$ quadrants in the pretrochal area. However, because the labeling was performed at the four-cell stage (and not later), it is hard to 
determine whether this expansion is driven by asymmetric growth of pre- or posttrochal derivatives.

Although the Carinoma prototroch does not possess specialized ciliation characteristic of typical prototrochs, we argue that it functions as a primary larval locomotory organ at the early stages of larval development (because it covers the majority of the surface). Our preliminary observations of the embryos around the time of onset of ciliation suggest that the equatorial region (comprising the trochal lineages) becomes ciliated before the apical regions, which corresponds to the early ciliation of the trochoblasts in mollusks and annelids. Later in development, the cells of the pretrochal and posttrochal region gradually take over the surface and the function of locomotion from the trochoblasts, which diminish in size and eventually are lost. Despite the common perception of the prototroch as a narrow band of cells with long compound cilia, broad uniformly ciliated prototrochs covering a substantial part of the larval surface are also found among other trochozoans, for example, protobranch bivalves (Drew 1899; Zardus and Morse 1998; Gustaffson and Reid 1986, 1988), neomenioid aplacophorans (Baba 1951; Thompson 1960; Okusu 2002), a sipunculid Sipunculus nudus (Gerould 1906), and nonfeeding eunicid and onuphid polychaete larvae (Pernet et al. 2002). Judging from the taxonomic distribution of these larval forms, they are likely to represent convergent similarity that illustrates the "evolvability" of larval ciliated cells in these animals.

What we thought to be a transitory larval ectoderm in Carinoma (which would be homologous to the larval tissues of a pilidium) turns out to be a vestigial prototroch. This challenges the previously suggested idea that a wholesale necrotic type of metamorphosis (as found in the pilidium) is a primitive character for the Nemertea (Jägersten 1972; Starobogatov 1979; Maslakova and Malakhov 1999). Instead, it suggests that development with a uniformly ciliated trochophore (as found in the basal nemertean Carinoma) might correspond to the ancestral type of development in nemerteans, whereas development with a highly modified pilidium larva and a subsequent loss of the whole pretrochal and trochal region is an autapomorphy of the nemertean clade Pilidiophora (Fig. 1). In this light, there is no justification for direct comparisons of nonnemertean larvae, like Müller's larva of the polyclad platyhelminthes (Nielsen 2001), with the nemertean pilidium. Unlike the prototroch of Carinoma and other trochozoan larvae, the pilidial ciliary band is formed by blastomeres of the first and second micromere quartets, as well as 3c and 3d (Henry and Martindale 1998) and the cells of the ciliated band appear to retain the ability to divide, judging from the cell number and size. Unlike Carinoma but similar to many other trochozoans, the ciliary band of the pilidium larva bears specialized cilia, different from those covering the rest of the larval surface. Lack of differential ciliation of the trochal lineage appears to be the condition found in all "planuliform" larvae of hoplonemerteans and palaeonemerteans. This implies that the differentially ciliated band of the pilidium larva evolved de novo and coopted novel cell lineages that do not contribute to prototrochs in other trochozoans. Thus, the highly stereotyped nature of spiral cleavage results in the independent cooption of similar and novel cell lineages for a similar function (a larval locomotory ciliary band) as had been previously suggested by Ivanova-Kazas (1986). It remains unclear whether the hoplonemertean transitory larval ectoderm also represents a modified prototroch or whether it is homologous to the whole pretrochal and trochal region of a pilidium. A detailed morphological study of hoplonemertean larvae, similar to that undertaken for Carinoma, would be necessary to refute either hypothesis. Until then the possibility remains that the transitory larval ectoderm found in some hoplonemerteans corresponds to the tissues lost during pilidial metamorphosis and that a necrotic metamorphosis is ancestral for the $\mathrm{Ne}$ onemertea, a clade including the Pilidiophora and the Hoplonemertea (Fig. 1).

The inferred ancestral presence of a trochophore in nemerteans fills the "gap" in the distribution of trochophore larvae among the Trochozoa (as defined by Peterson and Eernisse 2001) and allows a meaningful comparison between larval development of nemerteans and other trochozoans. A study of the timing and molecular mechanisms of differentiation of the trochoblast lineage in various trochozoans could strengthen the assertion of homology of the prototroch and other defined structures across the Trochozoa.

\section{Acknowledgments}

We are grateful to Dr. Mary Rice and the staff of the Smithsonian Marine Station at Fort Pierce and staff of the Friday Harbor Laboratories for their support and assistance. S. A. M. acknowledges Eric Edsinger-Gonzales and George von Dassow for guidance in confocal microscopy techniques. Eric Edsinger-Gonzales also provided a number of critical comments on the manuscript. This work was partially supported by NSF PEET grant DEB 97124463 to Diana Lipscomb and J. L. N., Link Foundation/Smithsonian Institution Graduate Fellowship to S. A. M., and NSF and NASA grants to M. Q. M. This is contribution no. 582 from the Smithsonian Marine Station at Fort Pierce.

\section{REFERENCES}

Baba, K. 1951. General sketch of the development in a Solenogastre, Epimenia verrucosa (Nierstrasz). Misc. Repts. Res. Inst. Nat. Res. 19-21: 38-46.

Beklemishev, V. N. 1964. Principles of the Comparative Anatomy of Invertebrates. University of Chicago Press, Chicago.

Buckland-Nicks, J., Gibson, G., and Koss, R. 2002a. Phylum Mollusca: Polyplacophora, Aplacophora, Scaphopoda. In C. M. Young (ed.). Atlas of Marine Invertebrate Larvae. Academic Press, San Diego, pp. 245-259.

Buckland-Nicks, J., Gibson, G., and Koss, R. 2002b. Phylum Mollusca: Gastropoda. In C. M. Young (ed.). Atlas of Marine Invertebrate Larvae. Academic Press, San Diego, pp. 261-287. 
Cantell, C. E. 1969. Morphology, development and biology of the pilidium larvae (Nemertini) from the Swedish West Coast. Zool. Bidrag. F. Uppsala 38: 61-111.

Chernyshev, A. V. 2000. Larvae of nemerteans of the family Ototyphlonemertidae in the plankton of Peter the Great Bay, Sea of Japan. Biol. Morya 26: 50-52 (in Russian).

Child, C. M. 1900. The early development of Arenicola and Sternaspis. Arch. Entw. Mech. 9: 587-723.

Costello, D. P. 1945. Experimental studies of germinal localization in Nereis. J. Exp. Zool. 100: 19-66.

Damen, P., and Dictus, W. J. A. G. 1994a. Cell lineage analysis of the prototroch of the gastropod mollusk Patella vulgata shows conditional specification of some trochoblasts. Roux's Arch. Dev. Biol. 203: 187-198.

Damen, P., and Dictus, W. J. A. G. 1994b. Cell lineage of the prototroch of Patella vulgata (Gastropoda, Mollusca). Dev. Biol. 162: 364-383.

Damen, P., and Dictus, W. J. A. G. 1996. Organizer role of the stem cell of the mesoderm in prototroch patterning in Patella vulgata (Mollusca, Gastropoda). Mech. Dev. 56: 41-60.

Dawydoff, C. 1940. Les formes larvaires de polyclades et de nemertines du plancton indochinois. Bull. Biol. Fr. Belg. 74: 443-496.

Delsman, H. C. 1915. Eifurchung und Gastrulation bei Emplectonema gracile Stimpson. Helder Tijdschr. Nederl. Dierk. Ver. 14: 68-114.

Drew, G. A. 1899. The anatomy, habits, and embryology of Yoldia limatula. Mem. Biol. Lab. J. Hopkins Univ. 4: 1-37.

Gerould, J. H. 1906. The development of Phascolosoma (studies on the embryology of the Sipunculidae II). Zool. Jahrb. Abt. Anat. Ont. Tiere 23: $77-162$.

Gustaffson, R. G., and Reed, R. G. B. 1986. Development of the pericalymma larva of Solemia reidi (Bivalvia: Cryptodonta: Solemyidae) as revealed by light and electron microscopy. Mar. Biol. 93: 411-427.

Gustaffson, R. G., and Reed, R. G. B. 1988. Larval and post-larval morphogenesis in the gutless protobranch bivalve Solemya reidi (Cryptodonta; Solemyidae). Mar. Biol. 97: 373-387.

Hammarsten, O. D. 1918. Beitrag zur Embryonalentwicklung der Malacobdella grossa (Müll.). Dissertation thesis. Uppsala, Almqvist and Wiksells Boktryckery A. B., 96 pp.

Henry, J. Q., and Martindale, M. Q. 1994. Establishment of the dorsoventral axis in nemertean embryos - evolutionary considerations of spiralian development. Dev. Gen. 15: 64-78.

Henry, J. J., and Martindale, M. Q. 1998. Conservation of the spiralian developmental program: cell lineage of the nemertean, Cerebratulus lacteus. Dev. Biol. 201: 253-269.

Hickman, V. V. 1963. The occurrence in Tasmania of the land nemertine, Geonemertes australiensis Dendy, with some account of its distribution, habits, variations and development. Pap. Proc. R. Soc. Tasmania 97: $63-75$.

Ivanova-Kazas, O. M. 1985. Origin and phylogenetic significance of the trochophoran larvae. 3. Larvae of flatworms and nemerteans. Zool. Zh. 64: 1765-1767 (in Russian).

Ivanova-Kazas, O. M. 1986. Origin and phylogenetic significance of the trochophoran larvae. 4. Kamptozoa larvae - general ideas. Zool. Zh. 65: 165-174 (in Russian).

Iwata, F. 1960. Studies on the comparative embryology of the nemerteans with special reference to their inter-relationships. Publ. Akkeshi Mar. Biol. Stn. 10: 1-51.

Jaeckle, W. B., and Rice, M. E. 2002. Phylum Sipuncula. In C. M. Young (ed.). Atlas of Marine Invertebrate Larvae. Academic Press, San Diego, pp. 375-396.

Jägersten, G. 1972. Evolution of the Metazoan Life Cycle. Academic Press, London.

Lacalli, T. C., and Gilmour, T. H. J. 2001. Locomotory and feeding effectors of the tornaria larva of Balanoglossus biminiensis. Acta Zool. 82: $117-126$.

Lacalli, T. C., and West, J. E. 1985. The nervous system of a pilidium larva: evidence from electron microscope reconstructions. Can. J. Zool. 63 : 1901-1916.

Martindale, M. Q., and Henry, J. Q. 1995. Modifications of cell fate specification in equal-cleaving nemertean embryos - alternate patterns of spiralian development. Development 121: 3175-3185.
Maslakova, S. A., and Malakhov, V. V. 1999. Hidden larva in the Hoplonemertini order of nemerteans. Dokl. Akad. Nauk. 366: 849-852.

Maslakova, S. A., Martindale, M. Q., and Norenburg, J. L. 2004. Fundamental properties of the spiralian developmental program are displayed by the basal nemertean, Carinoma tremaphoros (Palaeonemertea, Nemertea). Dev. Biol. 267: 342-360.

McBride, E. W. 1914. Text-Book of Embryology. Macmillan and Co., Ltd., London.

Nielsen, C. 1995. Animal Evolution. Interrelationships of the Living Phyla. Oxford University Press, Oxford.

Nielsen, C. 2001. Animal Evolution. Interrelationships of the Living Phyla. Oxford University Press, Oxford

Nielsen, C. 2002. Phylum Kamptozoa. In C. M. Young (ed.). Atlas of Marine Invertebrate Larvae. Academic Press, San Diego, pp. 397-409.

Norenburg, J. L., and Stricker, S. A. 2002. Phylum Nemertea. In C. M. Young (ed.). Atlas of Marine Invertebrate Larvae. Academic Press, San Diego, pp. 163-177.

Okusu, A. 2002. Embryogenesis and development of Epimenia babai (Mollusca Neomeniomorpha). Biol. Bull. 203: 87-103.

Pernet, B., Qian, P., Rouse, G., Young, C. M., and Eckelbarger, K. J. 2002. Phylum Annelida: Polychaeta. In C. M. Young (ed.). Atlas of Marine Invertebrate Larvae. Academic Press, San Diego, pp. 209-243.

Peterson, K. J., and Eernisse, D. J. 2001. Animal phylogeny and the ancestry of bilaterians: inferences from morphology and 18S rDNA gene sequences. Evol. Dev. 3: 170-205.

Pilger, J. E. 2002. Phylum Echiura. In C. M. Young (ed.). Atlas of Marine Invertebrate Larvae. Academic Press, San Diego, pp. 371-373.

Reinhardt, H. 1941. Beiträge zur Entwicklungsgeschichte der einheimischen Süßwassernemertine Prostoma graecense (Böhmig). Vierteljahrsschr. Naturf. Ges. Zürich. 86: 184-252.

Rouse, G. W. 1999. Trochophore concepts: ciliary bands and the evolution of larvae in spiralian metazoa. Biol. J. Lin. Soc. 66: 411-464.

Rouse, G. W. 2000. Bias? What bias? The evolution of downstream larvalfeeding in animals. Zool. Scr. 29: 213-236.

Salensky, W. 1886. Bau und Metamorphose des Pilidiums. Z. Wiss. Zool. 43: 481-511.

Starobogatov, Y. I. 1979. Evolution of the pelagic larvae of protostomia and problem of main body components. Zool. Zh. 58: 149-160 (in Russian)

Stricker, S. A., and Reed, C. G. 1981. Larval morphology of the nemertean Carcinonemertes epialti (Nemertea: Hoplonemertea). J. Morphol. 169: $61-70$.

Thollesson, M., and Norenburg, J. L. 2003. Ribbon worm relationships-a phylogeny of the phylum Nemertea. Proc. R. Soc. Lond. B Biol. 270: 407-415.

Thompson, T. E. 1960. The development of Neomenia carinata Tullberg (Mollusca, Aplacophora). Proc. R. Soc. B Biol. 153: 263-278.

Turbeville, J. M. 1986. An ultrastructural analysis of coelomogenesis in the hoplonemertine Prosorhochmus americanus and the polychaete Magelona sp. J. Morphol. 187: 51-60.

Turbeville, J. M. 2002. Progress in nemertean biology: development and phylogeny. Integr. Compar. Biol. 42: 692-703.

Turbeville, J. M., and Ruppert, E. E. 1985. Comparative ultrastructure and the evolution of nemertines. Am. Zool. 25: 53-71.

Turbeville, J. M., Field, K. G., and Raff, R. A. 1992. Phylogenetic position of phylum Nemertini, inferred from 18S ribosomal RNA sequences-molecular data as a test of morphological character homology. Mol. Biol. Evol. 9: 235-249.

Wilson, E. B. 1892. The cell lineage of Nereis: a contribution to the cytogeny of the annelid body. J. Morphol. 6: 361-480.

Wilson, E. B. 1904. Experimental studies in germinal localization: II. Experiments on the cleavage-mosaic in Patella and Dentalium. J. Exp. Zool. 1: 197-268.

Zardus, J. D., and Martel, A. L. 2002. Phylum Mollusca: Bivalvia. In C. M. Young (ed.). Atlas of Marine Invertebrate Larvae. Academic Press, San Diego, pp. 290-325.

Zardus, J. D., and Morse, M. P. 1998. Embryogenesis, morphology and ultrastructure of the pericalymma larva of Acila castrensis (Bivalvia: Protobranchia: Nuculoida). Invert. Biol. 117: 221-244. 